Milos Hitka - Silvia Lorincova - Martina Lipoldova - Zaneta Balazova - Denisa Debnarova

\title{
DIFFERENCES IN THE LEVEL OF WORKERS' MOTIVATION IN REPAIR AND MAINTENANCE SERVICE ENTERPRISE IN THE RAIL TRANSPORT
}

The time when the only job of a manager was to delegate work to employees is over. At the present time, an ability to motivate employees is considered an essential skill for managers. It is complex and systematic effort of a manager to create a working environment and atmosphere supporting the inner needs and interests of employees affecting their behaviour and stimulating the performance positively. Differences in the level of workers' motivation in repair and maintenance service enterprise in the rail transport was defined using the sample set of almost 1,000 respondents and ANOVA and Duncan test. Following the results, it can be stated that the structure of motivation factors, as well as their importance, changed significantly in repair and maintenance service enterprise in the rail transport over the observation period.

Keywords: human resource management, employee motivation, rail transport, ANOVA, Duncan test

\section{Introduction}

The entrepreneurial environment is influenced by globalisation of these days [1-2]. Because of tough competition preferred in the market economy, businesses are forced to improve enterprise effectiveness [3-4]. The pressure is put on developing effective strategies to succeed in a highly competitive environment [5-7]. If enterprises do not want to stagnate, they have to place the emphasis on modernisation, improving the quality, the effectiveness of activities in order to maintain and improve their competitiveness on the market [8-11]. This way, human resource management is a strategic and logical approach to managing the most valuable asset the companies possess, i.e. people hired by enterprises, contributing to their viability and competitiveness [12-15].

\section{Literature review}

One of the most serious problems of managers in the business environment is employee motivation [16-18]. Employee motivation affects the work results directly [1922]. It results in enterprise effectiveness and development [23-25]. It is a process reflecting the intensity, movement and efforts of an individual resulting in a goal directed behaviour of employees [26-27]. Motivation can be understood as a sequence of reactions when requirements and goals, causing some pressure, occur as a result of feelings and needs [28].

Motivation is one of the most important elements in human resource management. In order to affect employees positively, managers must recognise employees' needs and ways of effective motivation. That can lead to motivation programme covering the needs of enterprises, as well as employees. The presumption that motivation is only about money is not correct. Following the research [29-31], it can be stated that the effect of money on motivation is decisive, however the issue is much more complex because of various employees' goals, needs and goal directed behaviour, as well [32]. Their gender, age, education, status, family background, experience and abilities, etc. are different, therefore they can be motivated by different factors. Some employees want to be successful, recognised, expect career advancement, other employees consider relationships, working conditions, job position or job security to be more important [33-35]. For others working environment, management, training and professional development, salary, workplace, team work and relationship to co-workers [36], or healthy working conditions, career opportunity, supportive boss, unambiguous and definite goals, competitive compensation, interesting job, high prestige, good performance evaluation, pleasant working atmosphere, peaceful private life, competent leadership, appreciation, participation in decision-making and fringe benefits can be important, as well [37]. The aim of the paper is to define the differences in the level of workers' motivation in repair and maintenance service enterprise in the rail transport.

\section{$3 \quad$ Methodology}

The level of motivation was investigated using the data collected in the questionnaire asking about thirty motivation factors. Data were processed in the programme

Milos Hitka*, Silvia Lorincova, Martina Lipoldova, Zaneta Balazova, Denisa Debnarova

Technical University in Zvolen, Slovak Republic

*E-mail of corresponding author: hitka@tuzvo.sk 
STATISTICA 12. The differences in the level of bluecollar workers' motivation in repair and maintenance service enterprise in the rail transport were defined using the statistical analysis. The research did not differentiate employees by occupation, but focused on object research as a whole and followed the development of changes in motivation factors according to years 2003, 2009, 2016, 2019 and 2020. Position of the rail transport within the transport system in Slovakia is very specific. It is considered supporting, mass and ecological means of transport [38].

The research was carried out in repair and maintenance service enterprise in the rail transport over the years 2003, 2009, 2016, 2019 and 2020. Total of 968 respondents participated in the research. Composition of the sample set is given in Table 1.

Taro Yamane method was used to verify representativeness of the basic sampling unit [39]:

$n=\frac{N}{1+N(e)^{2}}$,

where:

$\mathrm{n}$ - size of the sample set,

$\mathrm{N}$ - size of the basic sampling unit (population)

e - permissible error/ level of precision.

Following the results, the representativeness of sampling units could be stated.

ANOVA test and Duncan test were conducted at the level of significance $\alpha=5 \%$ and $95 \%$ confidence to determine the hypothesis is true [40]. Following hypotheses were tested:

$W_{1}$ : we suppose that the workers' motivation in repair and maintenance service enterprise in the rail transport will be different in structure.

$\mathrm{WH}_{2}$ : we suppose that the workers' motivation in repair and maintenance service enterprise in the rail transport will be different in terms of importance.

\section{Results and discussion}

In the first step, the level of motivation in repair and maintenance service enterprise in the rail transport was defined. Results are presented in Table 2.

Due to the fact that the level of motivation in enterprises has changed over time, subsequently, the order of importance of motivation factors in the year 2020 was defined. Five most important motivation factors (career advancement, atmosphere in the workplace, good work team, self-actualization, job security) were investigated in more detail. Results are presented in Table 3 and Table 4.

Effect of years on the motivation factor "career advancement" is presented in Figure 1. The most significant decrease occurred in the year 2009 when there was a crisis in the Slovak economy and the employee motivation decreased in general. This effect was observed in the case of all the investigated motivation factors. Statistically significant differences were noticed in the year 2020, comparing to all the other years, besides 2003 when the effect on the career advancement was the same.

Effect of years on the motivation factor "atmosphere in the workplace" is shown in Figure 2. As in the case of the previous motivation factor, there were significant differences in the year 2009 in comparison to all investigated years (Table 5). Significant differences were confirmed also in the year 2019, comparing to all the investigated years.

Results of statistical testing of the third most important motivation factor "good work team" are presented in Table 6 and Figure 3. The importance of the investigated motivation factor has increased since the year 2016. Effect of the years 2009 and 2020 was statistically significant in comparison to other investigated years.

Importance of the motivation factor "self-actualization" is illustrated in Figure 4. In the years 2003, 2016 and 2019, approximately similar level of the motivation factor was observed, i.e. there was no significant effect of the years. On the other hand, statistically significant effects were confirmed in the year 2009 and 2020 (Table 7).

Statistically significant differences in the motivation factor "job security" observed in the years 2009 and 2020 are presented in Table 8 and Figure 5. At the same time, there were the most significant differences in the evaluation of the mentioned motivation factor.

Following the obtained results, it can be stated that there were statistically significant differences in perceiving the most important motivation factors (career advancement, atmosphere in the workplace, good work team, self-actualization, job security) in the investigated years (2003, 2009, 2016, 2019 and 2020).

Figures of arithmetic means and reliability (Figures 1 - 5) show that there was a significant decrease in selected motivation factors in the year 2009, especially due to the fact that the year 2009 was considered special because of a dramatic decline in economy by approximately $5 \%$. Slovak economy suffered the consequences of a decline in global demand resulting in a decrease in industrial production, in demand for transport services, in wholesale revenues and subsequent fall in demands in retails and services, as a result of making the staff redundant. Mentioned changes in economy affected running of the repair and maintenance service enterprise in the rail transport when the financial and economic crisis in 2009 resulted in differences in requirements for the level of employee motivation. During the following years, the differences can be due to fluctuation in motivation needs of employees, not only in terms of the order of importance, but in terms of statistical significance of differences in individual factors, as well. Those differences were caused especially by the enterprise requirements for the number of staff during the individual years, resulting from the production needs, when the total number of employees changed in time. Forasmuch as the job of a human resource manager is based on communication with employees and these changes were not discussed with them, the level of motivation factors must have changed. Following the mentioned facts, it can be stated that changes in communication between 
Table 1 Composition of the sample set

\begin{tabular}{cccccc}
\hline Year & 2003 & 2009 & 2016 & 2019 & 2020 \\
\hline Number of respondents & 240 & 190 & 181 & 197 & 160 \\
Total number of workers & 357 & 300 & 275 & 347 & 243 \\
\hline
\end{tabular}

Table 2 Average values of motivation factors

\begin{tabular}{|c|c|c|c|c|c|}
\hline Motivation factor & 2003 & 2009 & 2016 & 2019 & 2020 \\
\hline Atmosphere in the workplace & 4.77 & 3.29 & 4.69 & 4.44 & 4.87 \\
\hline Good work team & 3.88 & 3.94 & 3.79 & 4.07 & 4.77 \\
\hline Fringe benefits $\left(13^{\text {th }}, 14^{\text {th }}\right.$ salary $)$ & 4.39 & 3.01 & 4.25 & 4.21 & 4.57 \\
\hline Physical effort at work & 4.16 & 3.91 & 3.95 & 3.85 & 4.27 \\
\hline Job security & 3.99 & 3.19 & 4.07 & 3.79 & 4.60 \\
\hline Communication in the workplace & 3.68 & 3.09 & 3.23 & 3.91 & 4.55 \\
\hline Name of the company & 4.22 & 3.71 & 4.38 & 3.79 & 4.35 \\
\hline Opportunity to apply one's own ability & 4.95 & 3.31 & 4.58 & 4.26 & 4.53 \\
\hline Workload and type of work & 4.19 & 4.36 & 4.33 & 3.86 & 4.33 \\
\hline Information about performance result & 3.57 & 3.11 & 3.61 & 3.62 & 4.48 \\
\hline Self-actualization & 4.00 & 3.79 & 3.86 & 3.85 & 4.63 \\
\hline Work environment & 4.02 & 3.29 & 3.96 & 3.74 & 4.33 \\
\hline Employee performance & 3.81 & 2.57 & 3.72 & 3.81 & 4.37 \\
\hline Career advancement & 4.10 & 3.71 & 3.85 & 3.68 & 4.90 \\
\hline Competences & 4.01 & 3.00 & 3.98 & 3.55 & 4.13 \\
\hline Prestige & 3.86 & 4.10 & 3.76 & 3.53 & 4.20 \\
\hline Supervisor' s approach & 3.96 & 3.03 & 3.95 & 3.84 & 4.55 \\
\hline Individual decision-making & 3.61 & 3.40 & 3.33 & 3.65 & 4.47 \\
\hline Working hours & 4.44 & 2.63 & 4.09 & 3.78 & 4.53 \\
\hline Social benefits & 3.94 & 3.03 & 3.68 & 3.62 & 4.33 \\
\hline Fair appraisal system & 3.94 & 2.83 & 3.67 & 3.91 & 4.55 \\
\hline Stress & 4.18 & 3.21 & 4.38 & 4.07 & 4.48 \\
\hline Mental effort & 4.16 & 3.67 & 4.04 & 3.75 & 4.27 \\
\hline Mission of the company & 4.49 & 3.50 & 4.41 & 4.11 & 4.30 \\
\hline Region development & 2.87 & 3.30 & 2.92 & 3.18 & 4.23 \\
\hline Education and personal growth & 4.52 & 3.19 & 4.00 & 4.13 & 4.35 \\
\hline Company relation to the environment & 3.66 & 3.29 & 3.77 & 3.70 & 4.28 \\
\hline Free time & 3.15 & 3.60 & 3.43 & 3.46 & 4.12 \\
\hline Recognition & 4.41 & 3.07 & 4.50 & 3.87 & 4.42 \\
\hline Basic salary & 3.25 & 3.16 & 3.69 & 3.56 & 4.48 \\
\hline
\end{tabular}

managers and employees are essential for motivation factors being relatively stable.

An enterprise is a place where activities linked with its success are carried out [41-42]. All the areas of management must be in the centre of attention [43-45]. In order to succeed, an enterprise must be led by a competent person - manager [46-48]. He/she must have powers of concentration for employees as the human resources are according to actual trends, the greatest asset possessed by an enterprise [49]. Motivating staff to achieve goals is one of the most serious problems the managers have to face in the business environment [22, 24, 50-51]. The issue of employee motivation is considered to be one of the most important facts in the area of human resource management. It reflects a general approach of people to work and their willingness to work. Internal order of employees' needs and their personalities are the decisive factors, therefore the research on employee motivation and their satisfaction or dissatisfaction is required in order to suggest effective measures associated with motivation [52-53]. Not only the situation and the environment, but also factors like the age, gender, education, affecting the needs of an individual, 
must be taken into account. Personal, mental, financial as well as social factors cause the changes in employee motivation. According to Nadeem et al. [54], there are lots of variables affecting the level of motivation. The opinion of Ryan and Deci [55] is the same. They think that the levels of employee motivation differ
Following results presented here, it can be stated that significant changes in the structure of motivation factors, as well as changes in the importance of motivation factors, occurred in the investigated enterprise over time. Five most important motivation factors (career advancement, atmosphere in the workplace, good work

Table 3 ANOVA test for five most important motivation factors

\begin{tabular}{lcccccccc}
\hline Variance analysis & SS effect $^{1}$ & $\begin{array}{c}\text { DF } \\
\text { effect }^{2}\end{array}$ & PS effect $^{3}$ & SS error $^{4}$ & $\begin{array}{c}\text { SV } \\
\text { error }^{5}\end{array}$ & PS error $^{6}$ & F $^{7}$ & $\mathrm{p}^{8}$ \\
\hline Career advancement & 92.80863 & 4 & 23.20216 & 408.9283 & 512 & 0.798688 & 29.05034 & 0.000 \\
Atmosphere in the & 343.6109 & 4 & 85.90272 & 320.1961 & 513 & 0.624164 & 137.6285 & 0.000 \\
workplace & 111.5843 & 4 & 27.89607 & 240.9563 & 513 & 0.469700 & 59.39120 & 0.000 \\
Good work team & 113.4335 & 4 & 28.35837 & 297.5800 & 513 & 0.580078 & 48.88717 & 0.000 \\
Self-actualization & 208.3348 & 4 & 52.08371 & 305.3273 & 513 & 0.595180 & 87.50917 & 0.000 \\
Job security & & & & & & & & \\
\hline
\end{tabular}

Notes: ${ }^{1}$ SS effect - sum of squares, ${ }^{2} \mathrm{SV}$ effect- degree of freedom, ${ }^{3} \mathrm{PS}$ effect - intergroup variance, ${ }^{4} \mathrm{SS}$ error- sum of squares, ${ }^{5} \mathrm{SV}$ error - degree of freedom, ${ }^{6} P S$ error - within group variance, ${ }^{7} F$ - F-test, ${ }^{8} p$ - level of significance (5\%)

Table 4 Duncan test for the motivation factor Career advancement

\begin{tabular}{cccccc}
\hline Year & 2003 & 2009 & 2016 & 2019 & 0.368147 \\
2003 & & $0.000003^{*}$ & 0.050843 & $0.001898^{*}$ & $0.000009^{*}$ \\
2009 & $0.000003^{*}$ & & $0.000011^{*}$ & 0.208377 \\
2016 & 0.050843 & $0.000011^{*}$ & & $0.006050^{*}$ \\
2019 & $0.001898^{*}$ & $0.000009^{*}$ & 0.208377 & $0.000078^{*}$ \\
2020 & 0.368147 & $0.000004^{*}$ & $0.006050^{*}$ & $0.000078^{*}$ \\
\hline
\end{tabular}

Note: Single asterisk (*) indicates statistically significant differences at the level of significance $\alpha=5 \%$

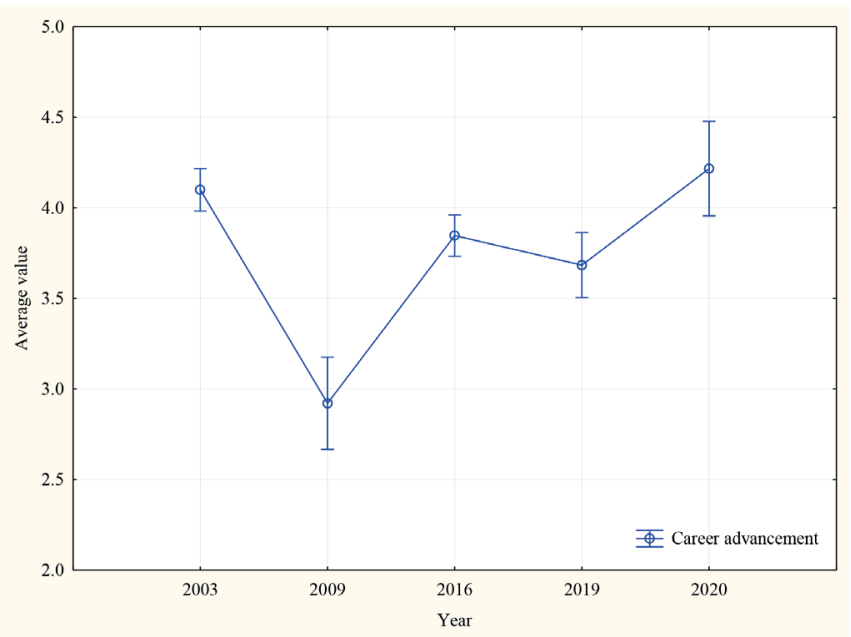

Figure 1 Arithmetic means and confidence interval for the motivation factor Career advancement

Table 5 Duncan test for the motivation factor Atmosphere in the workplace

\begin{tabular}{cccccc}
\hline Year & 2003 & 2009 & 2016 & 2019 & 0.0020 \\
2003 & & $0.000003^{*}$ & 0.497061 & $0.004742^{*}$ & $0.000009^{*}$ \\
2009 & $0.000003^{*}$ & & $0.000011^{*}$ & $0.024314^{*}$ & 0.154783 \\
2016 & 0.497061 & $0.000011^{*}$ & & $0.000327^{*}$ \\
2019 & $0.004742^{*}$ & $0.000009^{*}$ & $0.024314^{*}$ & $0.000327^{*}$ \\
2020 & 0.405392 & $0.000004^{*}$ & 0.154783 & \\
\hline
\end{tabular}

Note: Single asterisk (*) indicates statistically significant differences at the level of significance $\alpha=5 \%$ 


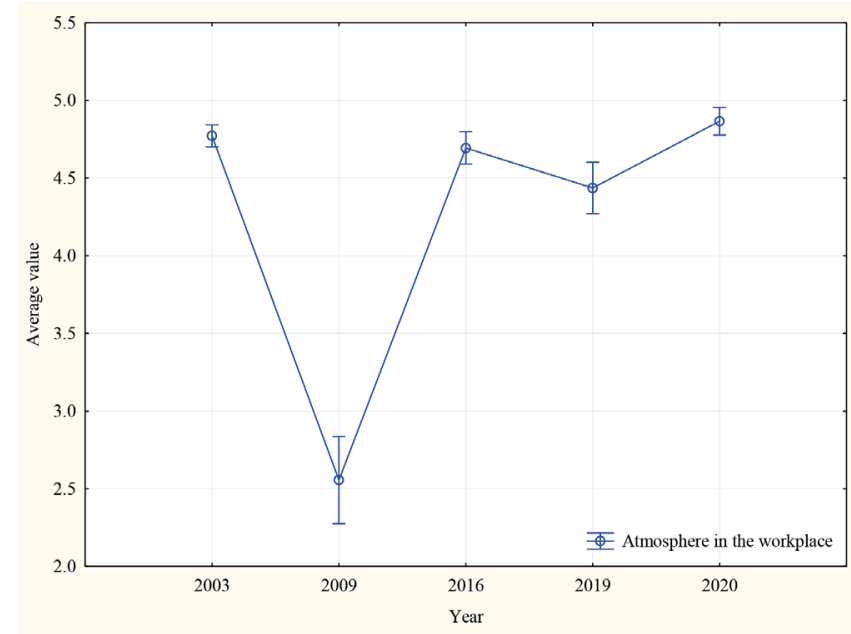

Figure 2 Arithmetic means and confidence interval for the motivation factor Atmosphere in the workplace

Table 6 Duncan test for the motivation factor Good work team

\begin{tabular}{cccccc}
\hline Year & 2003 & 2009 & 2016 & 2019 & 2020 \\
\hline 2003 & & $0.000011^{*}$ & 0.387662 & 0.055939 & $0.000011^{*}$ \\
2009 & $0.000011^{*}$ & & $0.000009^{*}$ & $0.000003^{*}$ & $0.000004^{*}$ \\
2016 & 0.387662 & $0.000009^{*}$ & & $0.007652^{*}$ & $0.000003^{*}$ \\
2019 & 0.055939 & $0.000003^{*}$ & $0.007652^{*}$ & & $0.000009^{*}$ \\
2020 & $0.000011^{*}$ & $0.000004^{*}$ & $0.000003^{*}$ & $0.000009^{*}$ & \\
\hline
\end{tabular}

Note: Single asterisk (*) indicates statistically significant differences at the level of significance $\alpha=5 \%$

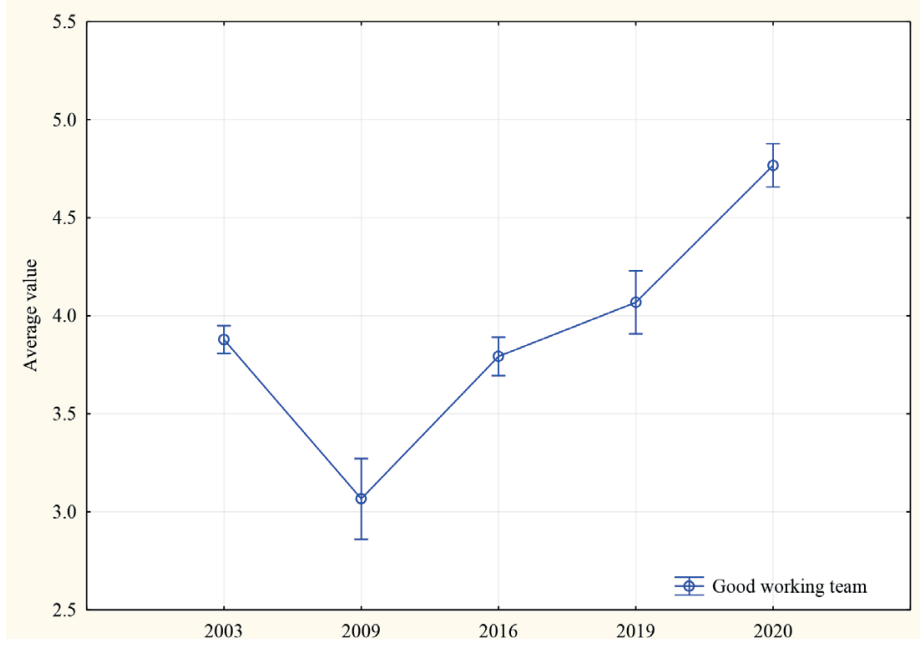

Figure 3 Arithmetic means and confidence interval for the motivation factor Good work team

Table 7 Duncan test for the motivation factor Self-actualization

\begin{tabular}{cccccc}
\hline Year & 2003 & 2009 & 2016 & 2019 & 2020 \\
\hline 2003 & & $0.000003^{*}$ & 0.191458 & 0.190006 & $0.000009^{*}$ \\
2009 & $0.000003^{*}$ & & $0.000011^{*}$ & $0.000009^{*}$ & $0.000004^{*}$ \\
2016 & 0.191458 & $0.000011^{*}$ & & 0.929945 & $0.000011^{*}$ \\
2019 & 0.190006 & $0.000009^{*}$ & 0.929945 & & $0.000003^{*}$ \\
2020 & $0.000009^{*}$ & $0.000004^{*}$ & $0.000011^{*}$ & $0.000003^{*}$ & \\
\hline
\end{tabular}

Note: Single asterisk (*) indicates statistically significant differences at the level of significance $\alpha=5 \%$ 


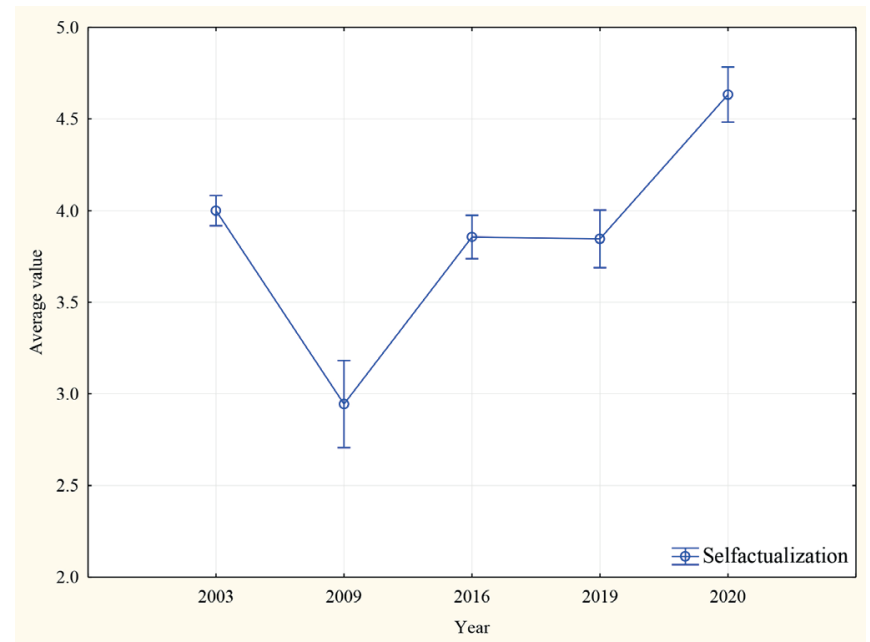

Figure 4 Arithmetic means and confidence interval for the motivation factor Self-actualization

Table 8 Duncan test for the motivation factor Job security

\begin{tabular}{cccccc}
\hline Year & 2003 & 2009 & 2016 & 2019 & 2020 \\
\hline 2003 & & $0.000011^{*}$ & 0.439757 & 0.087749 & $0.000011^{*}$ \\
2009 & $0.000011^{*}$ & & $0.000003^{*}$ & $0.000009^{*}$ & $0.000004^{*}$ \\
2016 & 0.439757 & $0.000003^{*}$ & & $0.017696^{*}$ & $0.000011^{*}$ \\
2019 & 0.087749 & $0.000009^{*}$ & $0.017696^{*}$ & & $0.000003^{*}$ \\
2020 & $0.000011^{*}$ & $0.000004^{*}$ & $0.000011^{*}$ & $0.000003^{*}$ & \\
\hline
\end{tabular}

Note: Single asterisk (*) indicates statistically significant differences at the level of significance $\alpha=5 \%$

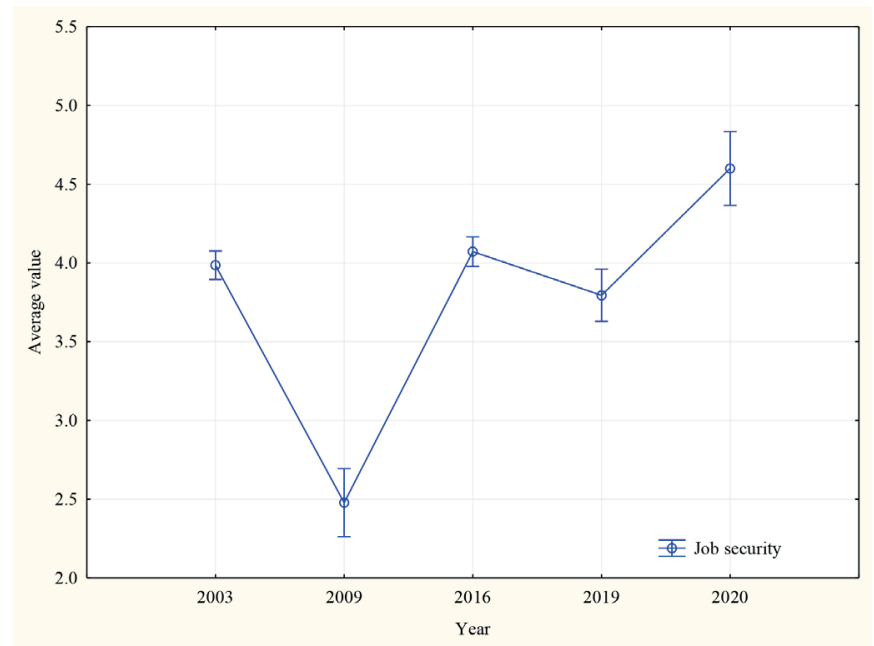

Figure 5 Arithmetic means and confidence interval for the motivation factor Job security

team, self-actualization, job security) changed. The order was determined following the order of importance in the year 2020. The results of the research, carried out by the questionnaire in the years 2003, 2009, 2019, 2019 and 2020 , showed the parts of employee motivation in which new measures resulting in their improvement must be taken. Following the findings, the hypotheses: the workers' motivation in repair and maintenance service enterprise in the rail transport will be different in structure and the workers' motivation in repair and maintenance service enterprise in the rail transport will be different in terms of importance, were confirmed.

\section{Conclusions}

Human resources are the essential factor determining the enterprise performance. Therefore, they must be in the centre of our attention. Employees can have abilities, skills, however if they are not willing to work, they do not achieve the required level of performance [56-57]. At this point, the employee motivation has to be taken into account as an important element affecting the employee performance. The main role of motivation is to ensure that the employees will be willing to work and achieve the greatest performance. Requirements for their performance 
are not as important as the needs to meet their personal requirements. General knowledge of theories associated with employee motivation is accepted in the research on motivation needs of employees and it is considered as the first step necessary for creating the motivation programme of an enterprise. Following the knowledge together with methods used in psychological and sociological research, the state-of-the-art of the human resources in an enterprise can be evaluated. Strength and weaknesses of the management and their impact on motivation can be defined this way as well.

The process of motivation is one of the most important elements of the human resource management [58]. Satisfaction of employees' needs affecting their behaviour and performance in positive way must be provided in order to have a required effect. Motivation programme covering the requirements of an enterprise and employees must be created. During the creating of a motivation programme, the most important motivation factors and their impacts on employees must be identified and modified to achieve the required effect.

The analysed enterprise can be recommended to carry out an analysis of the motivation factors in the course of twelve months. It should be aimed at defining the changes in the structure of motivation factors after implementing the measures to improve the motivation climate in the enterprise. In the case of further significant changes, the motivation programme must be modified to reflect the changes in employees' needs.

Employee motivation provided by supervisors managers should ensure that the work covers not only existential needs of employees but also makes the employees happy and satisfied. Managers must be aware of the fact that employees are human beings with their personal demands, wishes and goals. Therefore, each company should implement employees' needs, wishes and goals in the motivation factors and motivation programme. In this way, the motivation can result in satisfied and especially high performing staff that meet their personal needs in the workplace and at the same time they will fulfil the business goals. The main role of motivation is to ensure that employees are identified with their tasks at work and their personal goals are identical with those of the enterprise. Each enterprise should be aware of this fact and therefore turn more attention to employee motivation.

\section{Acknowledgements}

This research was supported by project KEGA 005TU Z-4/2020, Economics, Management and Enterprising in Wood Industry Companies - University Textbook with Visualization Support in Virtual Space.

\section{References}

[1] HAJDUCHOVA, I., HLAVACKOVA, P. Impact of global economy of forestry and forest based industry in the Czech and Slovak republic (in Slovak). Acta Facultatis Xylologiae. 2014, 56(2), p. 135-146. ISSN 1336-3824.

[2] KOHNOVA, L., PAPULA, J., SALAJOVA, N. Internal factors supporting business and technological transformation in the context of industry 4.0. Business: Theory and Practice [online]. 2019, 20, p. 137-245. ISSN 1648-0627, eISSN 18224202. Available from: https://doi.org/10.3846/btp.2019.13

[3] ANYAKOHA, C. Job analysis as a tool for improved organizational performance of SMEs in Lagos, Nigeria. Central European Journal of Labour Law and Personnel Management. 2019, 2(1), p. 7-16. eISSN 2644-4542. Available from: https://doi.org/10.33382/cejllpm.2019.02.01

[4] MAJERCAK, P., MAJERCAKOVA, E., NEDELIAKOVA, E. Management of optimization in logistics leads to savings in transport costs. In: 18th International Conference on Transport Means Transport Means 2014: proceedings. 2014. p. 364-367.

[5] NEDEliAKOVA, E., STEFANCOVA, V., KUDLAC, S. Six sigma and dynamic models application as an important quality management tool in railway companies. Procedia Engineering [online]. 2017, 187, p. 242-248. ISSN 1877-7058. Available from: https://doi.org/10.1016/j.proeng.2017.04.371

[6] NYUUR, R., BRECIC, R., MURPHY, P. Managerial perceptions of firms' corporate sustainability strategies: Insights from Croatia. Sustainability [online]. 2020, 12(1), 251. eISSN 2071-1050. Available from: https://doi.org/10.3390/ su12010251

[7] HORVATH, Z. S., HOLlOSY, V. G. The revision of Hungarian public service motivation (PSM) model. Central European Journal of Labour Law and Personnel Management [online]. 2019, 2(1), p. 17-28. eISSN $2644-4542$. Available from: https://doi.org/10.33382/cejllpm.2019.02.02

[8] NEDELIAKOVA, E., KUKA, A., SULKO, P., HRANICKY, M. An innovative approach to monitoring the synergies of extraordinary events in rail transport. In: 22nd International Scientific on Conference Transport Means 2018: proceedings. 2018. p. 28-32.

[9] NEMEC, M., KRISTAK, L., HOCKICKO, P., DANIHELOVA, Z., VELMOVSKA, K. Application of innovative P\&E method at technical universities in Slovakia. Eurasia Journal of Mathematics Science and Technology Education [online]. 2017, 13(6), p. 2329-2349. ISSN 1305-8215, eISSN 1305-8223. Available from: https://doi.org/10.12973/eurasia.2017.01228aa 
[10] MADLENAKOVA, L., MATUSKOVA, M., HRUDKAY, K. Intermodal transport terminals as part of the postal transportation network. In: 20th International Scientific on Conference Transport Means 2016: proceedings. 2016. p. 556-561.

[11] PALUS, H., PAROBEK, J., LIKER, B. Trade performance and competitiveness of the Slovak wood processing industry within the Visegrad Group Countries. Drvna Industrija [online]. 2015, 66(3), p. 195-203. ISSN 0012-6772, eISSN 1847-1153. Available from: https://doi.org/10.5552/drind.2015.1431

[12] KUCHARCIKOVA, A., MICIAK, M. Human capital management in transport enterprises with the acceptance of sustainable development in the Slovak Republic. Sustainability [online]. 2018, 10(7), p.1-18. eISSN 2071-1050. Available from: https://doi.org/10.3390/su10072530

[13] GOTTWALD, D., SVADLENKA, L., LEJSKOVA, P., PAVLISOVA, H. Human capital as a tool for predicting development of transport and communications sector: The Czech Republic perspective. Communications - Scientific Letters of the University of Zilina [online]. 2017, 19(4), p. 50-56. ISSN 1335-4205, eISSN 2585-7878. Available from: http://komunikacie.uniza.sk/index.php/communications/article/view/270

[14] FEJFAROVA, M., URBANCOVA, H. Human resource management in small and medium-sized enterprises in the Czech Republic. Scientific Papers of the University of Pardubice, Series D: Faculty of Economics and Administration [online]. 2016, 23(36), p. 79-90. ISSN 1211-555X, eISSN 1804-8048. Available from: http://hdl.handle.net/10195/64718

[15] ARMSTRONG, M., TAYLOR. S. Human resource management: modern concepts and procedures / Rizeni lidskych zdroju: moderni pojeti a postupy (in Czech). 13. ed. Praha: Grada Publishing, 2015. ISBN 978-80-247-5258-7.

[16] LATHAM, G. P. Work motivation: history, theory, research, and practice [online]. Thousand Oaks, California: Sage, 2007. ISSN 9781412990936, eISSN 9781506335520. Available from: http://dx.doi.org/10.4135/9781506335520

[17] LATHAM, G. P., PINDER, C. C. Work motivation theory and research at the dawn of the twenty-first century. Annual Review of Psychology [online]. 2005, 56, p. 485-516. eISSN 1545-2085. Available from: https://doi.org/10.1146/annurev. psych.55.090902.142105

[18] RICHER, S. F., BLANCHARD, C., VALLERAND, R. J. A motivational model of work turnover. Journal of Applied Social Psychology [online]. 2002, 23, p. 2089-2113. eISSN 1559-1816. Available from: https://doi.org/10.1111/j.1559-1816.2002. tb02065.x

[19] FALETAR, J., JELACIC, D., SEDLIACIKOVA, M., JAZBEC, A., HAJDUCHOVA, I. Motivating employees in a wood processing company before and after restructuring. BioResources [online]. 2016, 11(1), p. 2504-2515. ISSN 1930-2126. Available from: https://doi.org/10.15376/biores.11.1.2504-2515

[20] KHAN, M. I. The impact of training and motivation on performance of employees. Business Review. 2012, 7(2), p. 84-95. ISSN 1990-6587.

[21] KROPIVSEK, J., JELACIC, D., GROSELJ, P. Motivating employees of Slovenian and Croatian wood-industry companies in times of economic downturn. Drvna Industrija [online]. 2011, 62, p. 97-103. ISSN 0012-6772, eISSN 1847-1153. Available from: https://doi.org/10.5552/drind.2011.1040

[22] WEBEROVA, D., LIZBETINOVA, L. Consumer attitudes towards brands in relation to price. In: 27th International Business Information Management Association Conference Innovation Management and Education Excellence Vision 2020: From Regional Development Sustainability to Global Economic Growth: proceedings. 2016. p. 1850-1859. ISBN 978-0-9860419-6-9, p. 1850-1859.

[23] KANFER, R., CHEN, G., PRITCHARD, R. D. Work motivation: forging new perspectives and directions in the postmillenium. In: Work motivation: past, present, and future. KANFER, R., CHEN, G., PRITCHARD, R. D. (eds). New York: Taylor \& Francis, 2008. ISBN 978-0805857450, p. 601-631.

[24] QAYYUM, A. An empirical analysis of employee motivation and the role of demographics. Global Business and Management Research. 2012, 4(1), p. 1-14. eISSN 1947-5667.

[25] RUZZIER, M., KONECNIK RUZZIER, M. On the relationship between firm size, resources, age at entry and internationalization: The case of Slovenian SMEs. Journal of Business Economics and Management [online]. 2014, 16(1), p.52-73. ISSN 1611-1699, eISSN 2029-4433. Available from: https://doi.org/10.3846/16111699.2012.745812

[26] ROBBINS, S. P., JUDGE, T. A. Organizational behavior. Nai Dilli: Pearson Education Limited, 2014. ISBN 9780132834872

[27] BARTOL, K. M., MARTIN, D. C. Management. 3. ed. New York: McGraw Hill, 1998. ISBN 978-0070050785.

[28] KOONTZ, H., WEIHRICH, H. Management. Praha: Victoria Publishing, 1993. ISBN 80-85605-45-7.

[29] CONTIU, L. C., GABORA, M. R., OLTEANA, F. D. Employee's motivation from a cultural perspective - a key element of the hospitality industry competitiveness. Procedia Economics and Finance [online]. 2012, 3, p. 981-986. ISSN 2212-5671. Available from: https://doi.org/10.1016/S2212-5671(12)00261-4

[30] GHIMIRE, J., GUPTA, R. P., KUMAL, A. B., MAHATO, R. K., BHANDARI, R. M., THAPA, N. Factors associated with the motivation and de-motivation of health workforce in Nepal. Journal of Nepal Health Research Council. 2013, 11(24), p. 112-118. ISSN 1727-5482, eISSN 1999-6217.

[31] MILNE, P. Motivation, incentives and organizational culture. Journal of Knowledge Management [online]. 2007, 11(6), p. 28-38. ISSN 1367-3270. Available from: https://doi.org/10.1108/13673270710832145 
[32] CHARVAT, J. Corporate strategies for practice: a practical guide for managers and entrepreneurs: from corporate culture to the ability to make money: examples and studies from practice in Czech Republic / Firemni strategie pro praxi: prakticky navod pro manazery a podnikatele: Od firemni kultury po schopnost vydelavat penize: priklady a studie z praxe $v$ CR (in Czech). 1. ed. Praha: Grada, 2006. ISBN 80-247-1389-6.

[33] DOBRE, O. I. Employee motivation and organizational performance. Review of Applied Socio- Economic Research. 2013, 5(1), p. 53-60. ISSN 2247-6172.

[34] BAAH, K., AMOAKO, G. K. Application of Frederick Herzberg's two-factor theory in assessing and understanding employee motivation at work: a Ghanaian perspective. European Journal of Business and Management. 2011, 3(9), p. 1-8. ISSN 2222-1905, eISSN 2222-2839.

[35] HERZBERG, F. One more time: how do you motivate employees? Harvard Business Review [online]. 2008, 81(1), p. 87-96. ISSN 0017-8012. Available from: https://doi.org/10.1007/978-1-349-02701-9_2

[36] ANITHA, J. Determinants of employee engagement and the impact on employee performance. International Journal of Productivity and Performance Management [online]. 2014, 63(3), p. 308-323. ISSN 1741-0401. Available from: https://doi.org/10.1108/IJPPM-01-2013-0008

[37] IMHOF, E. Comparing occupational and gender differences on motivational structure. Periodica Polytechnica Social and Management Sciences. 2003, 11(2), p. 237-247. ISSN 1416-3837, eISSN 1587-3803.

[38] NEDELIAKOVA, E., SEKULOVA, J., NEDELIAK, I., MAJERCAK, P. Services in railway passenger transport and its evaluation by dynamic models. In 18th International Conference on Transport Means Transport Means 2014: proceedings. 2014. p. 227-230.

[39] RICHTEROVA, K., LABSKA, H., KLEPOCHOVA, D., VOKOUNOVA, D., ZAK, S. Chapters from marketing research / Kapitoly z marketingoveho vyskumu (in Slovak). 2. ed. Bratislava, Slovakia: Ekonomicka univerzita, 2000. ISBN 80-225-1312-1.

[40] MASON, R. D., LIND, D. A. Statistical techniques in business and economics. 7. ed. Homewood, IL: Irwin, 1990. ISBN 0256076960.

[41] BlSTAKOVA, J., JONIAKOVA, Z., SKORKOVA, Z., NEMETHOVA, I., BEDNAR, R. Causes and implications of the applications of the individualisation principle in human resources management. AD ALTA: Journal of Interdisciplinary Research [online]. 2019, 9(2), p. 323-327. ISSN 1804-7890, eISSN 2464-6733. Available from: https:// doi.org/10.33543/0902

[42] JANKELOVA, N., JONIAKOVA, Z., BLSTAKOVA, J., NEMETHOVA, I. Readiness of human resource departments of agricultural enterprises for implementation of the new roles of human resource professionals. Agricultural Economics [online]. 2017, 63(10), p. 461-470. ISSN 0139-570X, eISSN v 1805-9295. Available from: https://doi.org/10.17221/189/2016-AGRICECON

[43] KUCHARCIKOVA, A., TOKARCIKOVA, E., KLUCKA, J., KONUSIKOVA, L. Foreign direct investment: Impact on sustainable development in regions of Slovak Republic. Journal of Security and Sustainability Issues [online]. 2015, 5(1), p. 59-71. ISSN 2029-7025. Available from: https://doi.org/10.9770/jssi.2015.5.1(5)

[44] NEDELIAKOVA, E., SEKULOVA, J., NEDELIAK, I. Reduction of transport risks at rail level crossings. In: 19th International Scientific Conference on Transport Means, Transport Means 2015: proceedings. 2015. p. 236-239.

[45] SEDLIACIKOVA, M., STROKOVA, Z., DRABEK, J., MALA, D. Controlling implementation: what are the benefits and barries for employees of wood processing enterprises? Acta Facultatis Xylologiae [online]. 2019, 61(2), p. 163-173. ISSN 1336-3824. Available from: https://doi.org/10.17423/afx.2019.61.2.15

[46] SERTIC, M. B., BARCIC, A. P., KLARIC, K. Economic determinants and analysis of the European Union wood industry SMEs employment. BioResources [online]. 2018, 13(1), p. 522-534. ISSN 1930-2126. Available from: https://doi.org/10.15376/biores.13.1.522-534

[47] LIZBETINOVA, L. Clusters of Czech consumers with focus on domestic brands. In: 29th International Business Information Management Association Conference Education Excellence and Innovation Management through Vision 2020: From Regional Development Sustainability to Global Economic Growth: proceedings. 2017. p. 1703-1718.

[48] ZABOROVA, E. N., GLAZKOVA, I. G., MARKOVA, T. L. Distance learning: students' perspective. Sociological Studies / Sotsiologicheskie Issledovaniya. 2017, 2, p. 131-139. ISSN 0132-1625.

[49] KIMENGSI, J. N., BHUSAL, P., ARYAL, A., FERNANDEZ, M. V. B. C., OWUSU, R., CHAUDHARY, A. NIELSEN, W. What (de)motivates forest users' participation in co-management? Evidence from Nepal. Forests [online]. 2019, 10 (6), 512. eISSN 1999-4907. Available from: https://doi.org/10.3390/f10060512

[50] KUMAR, N. S., HAQUE, M. I., VENUGOPAL, K. Employment challenges in Saudi Arabia: An attitudinal study. Entrepreneurship and Sustainability Issues [online]. 2019, 6(4), p. 1637-1646. eISSN 2345-0282. Available from: https://doi.org/10.9770/jesi.2019.6.4(6)

[51] HAJDUKOVA, A. Impact of regional differences on apprehending of the significance of labour factors motivating the employees of woodworking industry on Slovakia. Acta Facultatis Xylologiae. 2014, 56(1), p. 119-128. ISSN 1336-3824. 
[52] SHAHREKI, J., GANESAN, J., RAMAN, K., CHIN, A. L. L., CHIN, T. S. The effect of human resource information system application on employee satisfaction and turnover intention. Entrepreneurship and Sustainability Issues [online]. 2019, 7(2), p. 1462-1479. eISSN 2345-0282. Available from: https://doi.org/10.9770/jesi.2020.7.3(47)

[53] STACHOVA, K., STACHO, Z., BLSTAKOVA, J., HLATKA, M., KAPUSTINA, L. M. Motivation of employees for creativity as a form of support to manage innovation processes in transportation-logistics companies. Nase More: International Journal of Maritime Science and Technology [online]. 2018, 65(4), p. 180-186. ISSN 0469-6255, eISSN $1848-6320$. Available from: https://doi.org/10.17818/NM/2018/4SI.3

[54] NADEEM, M., RANA, M. S., LONE, A. H., MAQBOOL, S., NAZ, K., ALI, A. Teacher's competencies and factors affecting the performance of female teachers in Bahawalpur (Southern Punjab) Pakistan. International Journal of Business and Social Science. 2011, 2(19), p. 217-222. ISSN 2219-1933, eISSN 2219-6021.

[55] RYAN, R. M., DECI, E. L. Intrinsic and extrinsic motivations: classic definitions and new directions. Contemporary Educational Psychology [online]. 2000, 25(1), p. 54-67. ISSN 0361-476X. Available from: https://doi.org/10.1006/ ceps.1999.1020

[56] PLENKINA, V. V., OSINOVSKAYA, I. V. Improving the system of labor incentives and stimulation in oil companies. Entrepreneurship and Sustainability Issues [online]. 2018, 6(2), p. 912-926. eISSN 2345-0282. Available from: https://doi.org/10.9770/jesi.2018.6.2(29)

[57] KAMPF, R., HLATKA, M., SAVIN, G. Proposal for optimizing specific distribution routes by means of the specific method of operational analysis. Communications - Scientific Letters of the University of Zilina [online]. 2017, 19(2), p. 133-138. ISSN 1335-4205, eISSN 2585-7878. Available from: http://komunikacie.uniza.sk/index.php/communications/ article/view/197

[58] STACHOVA, K., STACHO, Z., VICEN, V. Efficient involvement of human resources in innovations through effective communication. Business: Theory and Practice [online]. 2017, 18, p. 33-42. ISSN 1648-0627, eISSN $1822-4202$. Available from: https://doi.org/10.3846/btp.2017.004 